\title{
Rainfall Forecasting Using Backpropagation Neural Network: A Case in of North Luwu, Indonesia
}

\author{
Ansari Saleh Ahmar ${ }^{1}$, Muhammad Arif Tiro², Ria Putri Utama ${ }^{3}$ \\ \{ansarisaleh@unm.ac.id ${ }^{1}$, arif_tiro@unm.ac.id ${ }^{2}$, riaputriutami.rpu@gmail.com ${ }^{3}$ \} \\ Department of Statistics, Universitas Negeri Makassar, Daeng Tata Street, Makassar, Indonesia ${ }^{1,2,3}$
}

\begin{abstract}
Climate information is seen as important in helping society, especially in the agricultural sector. In this regard, it is necessary to forecast rainfall which is one of the major factors associated with global climate change. ARIMA Method is a popular method used in forecasting. However, the method in use was based on several assumptions and is not considered independent variables in making forecasting. To anticipate the non-fulfillment of assumptions in the ARIMA method Box - Jenkins and to further streamline the results of forecasting by using free variables in forecasting, another method that can be used is backpropagation neural network. This study aims to predict rainfall in North Luwu District use backpropagation neural network method. From the research results obtained the best model i.e. architecture $(5,4,1)$ for backpropagation neural network method with RMSE 95,41.
\end{abstract}

Keywords: Please list your keywords in this section.

\section{Introduction}

Climate information is a key need to support activities in various sectors. This information is particularly useful in the agricultural sector, especially for deep farmers anticipating weather related possibilities that would result in a failure in the production process. One of the areas in South Sulawesi Provincial majority work in agriculture, forestry, hunting, and fishing are the districts of North Luwu. Based on data from the Central Bureau of Statistics (BPS), it is known that from 132. 030 workforce population in regency of North Luwu, 61\% work in that sector, with wide agricultural area i.e. 58,862 hectares (CPM, 2016). Palm oil and cocoa are superior plantation commodities from the Regency North Luwu. In addition, almost all food crops such as rice, maize, cassava is also available in the districts mentioned.

According to Indrabayu (2013), climate forecasting methods used by BMKG such as Regression Model, Autoregressive Integrated Moving Average (ARIMA) [1-4], Neural Network [5][6], and Adaptive Neuro-Fuzzy Inference Systems (ANFIS ) [7][8]. ARIMA Method for seasonal data is one of the most commonly used for forecasting. ARIMA method is methods that completely ignores the free variables in making predictions, and only use past and present values of the bound variables to generate forecasting. In case of rainfall, ARIMA method just make predictions based on the precipitation data of the previous period without considering other factors that affect such temperature, solar radiation, water humidity, as well as wind speed. In addition, the ARIMA method is also limited by several assumptions and only used for linear patterned data. Methods that can be used to pass the 
forecast and can overcome the weakness of ARIMA method one of them is Artificial Neural Network (ANN) or Neural Network (ANN) method, because the ANN method is not limited by assumption as in ARIMA method.

\section{Literature Review}

The main text should be written using Times New Roman, 10pt, fully justified. Italics can be used for emphasis and bold typeset should be avoided. Algorithm backpropagation on a continuous basis detailed [9][10]:

Stage beginning ( steps 0-2).

Step 0. Initialize weights from $x_{i}$ to $z_{j}$ and from $z_{j}$ to $y$ with the lowest possible random value, specify a minimal error value.

Step 1. As long as the stop condition has not been passed then do steps 2-8.

Step 2. For each pair of input data, do steps $3-8$.

Stage propagation forward or feedforward ( steps 3 - 5).

Step 3. Every neuron on screen input $\left(x_{i}, i=1, \ldots, n\right)$ receive the signal $x_{i}$ and spread the signal to all hidden screens.

Step 4. Every neuron on screen hidden $\left(z_{j}, j=1, \ldots, p\right)$ summed with each weighted input $\operatorname{signal}\left(\mathrm{v}_{\mathrm{ij}}\right)$ and bias $\left(\mathrm{v}_{\mathrm{oj}}\right)$.

$$
\mathrm{z}_{-} \mathrm{in}_{\mathrm{j}}=\mathrm{v}_{\mathrm{oj}}+\sum_{\mathrm{i}=1}^{\mathrm{n}} \mathrm{x}_{\mathrm{i}} \mathrm{v}_{\mathrm{ij}}
$$

the output signal is calculated by the activation function,

$$
\mathrm{z}_{\mathrm{j}}=\mathrm{f}\left(\mathrm{z}_{-} \mathrm{in} \mathrm{j}_{\mathrm{j}}\right)
$$

and sends the result to every neuron on the screen above it (output neurons).

Step 5 . Every neuron on screen output $\left(\mathrm{y}_{\mathrm{k}}, \mathrm{k}=1, \ldots, \mathrm{m}\right)$ summed with each weighted signal $\left(\mathrm{w}_{\mathrm{jk}}\right)$ and bias $\left(\mathrm{w}_{\mathrm{ok}}\right)$,

$$
\mathrm{y}_{-} \mathrm{in}_{\mathrm{k}}=\mathrm{w}_{\mathrm{ok}}+\sum_{\mathrm{j}=1}^{\mathrm{p}} \mathrm{z}_{\mathrm{j}} \mathrm{w}_{\mathrm{jk}}
$$

the output signal activation function is calculated by,

$$
\mathrm{y}_{\mathrm{k}}=\mathrm{f}\left(\mathrm{y}_{-} \mathrm{in}_{\mathrm{k}}\right)
$$

Stage propagation backward error value or backpropagation of error ( step 6 - 7) .

Step 6. Every neuron on output screen $\left(\mathrm{y}_{\mathrm{k}}, \mathrm{k}=1, \ldots, \mathrm{m}\right)$ receive target pattern $\left(\mathrm{t}_{\mathrm{k}}\right)$ that matches the training input pattern, compute the factor error on screen output $\left(\delta_{\mathrm{k}}\right)$,

$$
\delta_{\mathrm{k}}=\left(\mathrm{t}_{\mathrm{k}}-\mathrm{y}_{\mathrm{k}}\right) \mathrm{f}^{\prime}\left(\mathrm{y}_{-} \mathrm{in}_{\mathrm{k}}\right)
$$

calculate the correction weights with,

$$
\Delta \mathrm{w}_{\mathrm{jk}}=\alpha \delta_{\mathrm{k}} \mathrm{z}_{\mathrm{j}}
$$

calculate the correction biased with,

$$
\Delta \mathrm{w}_{\mathrm{ok}}=\alpha \delta_{\mathrm{k}}
$$

next value $\delta_{\mathrm{k}}$ used on the screen below.

Step 7. Every neuron on hidden screen $\left(z_{j}, j=1, \ldots, k\right)$ summed with value $\delta_{k}$ that has been given the weight of the screen above it, 


$$
\delta_{-} \mathrm{in}_{\mathrm{j}}=\sum_{\mathrm{k}=1}^{\mathrm{m}} \delta_{\mathrm{k}} \mathrm{w}_{\mathrm{jk}}
$$

Next calculate the value $\delta_{\mathrm{j}}$ with,

$$
\delta_{\mathrm{j}}=\delta_{-} \mathrm{in}_{\mathrm{j}} \mathrm{f}^{\prime}\left(\mathrm{z}_{-} \mathrm{in}_{\mathrm{j}}\right)
$$

calculate the correction weights with,

$$
\Delta v_{i j}=\alpha \delta_{j} x_{i}
$$

calculate the correction biased with,

$$
\Delta \mathrm{v}_{\mathrm{oj}}=\alpha \delta_{\mathrm{j}}
$$

Stage of calculation new weight (steps 8-9).

Step 8. Every neuron on screen output $\left(\mathrm{y}_{\mathrm{k}}, \mathrm{k}=1, \ldots, \mathrm{m}\right)$ renewing weight bias and the screen,

$$
\begin{aligned}
\mathrm{w}_{\mathrm{ok}}(\text { baru }) & =\mathrm{w}_{\mathrm{ok}}(\text { lama })+\Delta \mathrm{w}_{0 \mathrm{k}} \\
\mathrm{w}_{\mathrm{jk}}(\text { baru }) & =\mathrm{w}_{\mathrm{jk}}(\text { lama })+\Delta \mathrm{w}_{\mathrm{jk}}
\end{aligned}
$$

Every neuron on hidden screen $\left(z_{j}, j=1, \ldots, p\right)$ updating the bias and screen weights with,

$$
\begin{aligned}
v_{o j}(\text { baru }) & =v_{o j}(\text { lama })+\Delta v_{o j} \\
v_{i j}(\text { baru }) & =v_{i j}(\text { lama })+\Delta v_{i j}
\end{aligned}
$$

Step 9. Test the condition of the process stopped.

\section{Research Method}

This research is a quantitative research that is descriptive comparative. Data in this research is documentation data climate monthly in Luwu Utara obtained through BMKG office, station observation meteorological class III Andi Jemma Masamba, North Luwu, Indonesia. Data in this research used monthly data for 10 years that is start from January 2008 to July 2017. The training data consists of 108 data, ie data from January 2008 to December 2016. The test data consists of 7 data, i.e. data from January 2017 to July 2017. In the study, It is used six variables, namely, rainfall $(\mathrm{Y})$, temperature $\left(\mathrm{X}_{1}\right)$, solar radiation length $\left(\mathrm{X}_{2}\right)$, humidity $\left(\mathrm{X}_{3}\right)$, wind speed $\left(\mathrm{X}^{4}\right)$, and previous rainfall period $\left(\mathrm{X}^{5}\right)$.

Steps analysis, namely:

1. Analysis data using method backpropagation neural network .

a) Normalization of data.

b) Training for get amount layer hidden the best.

c) Training for get number of best neurons on layer hidden.

d) Testing for look accuracy architecture that has been obtained in do forecasting.

2. Selecting best method with use criteria out-sample with compare value Root Mean Square Error (RMSE) and coefficient correlation from each methods .

3. Forecasting with the best method.

\section{Result and Discussion}

\subsection{Training for the number of hidden layers}




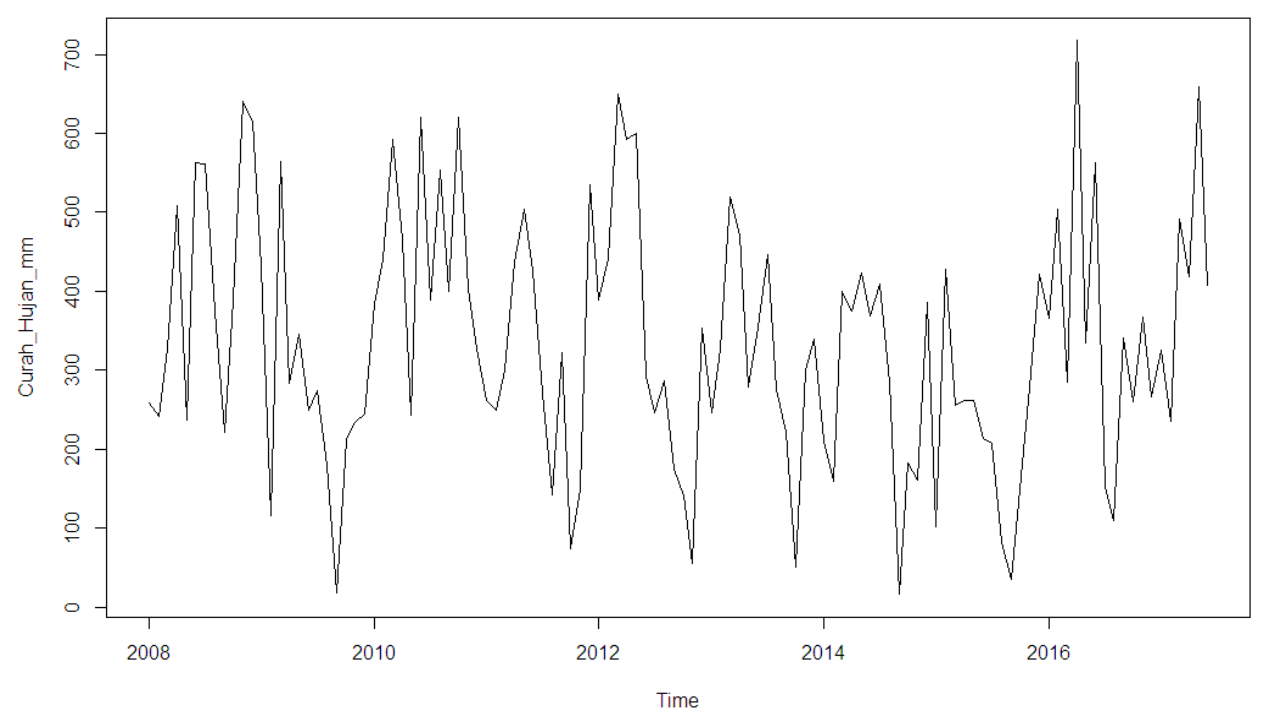

Fig. 1. Time Series Plot of Rainfall in North Luwu form Januari 2008 - Juni 2017

Table 1. Rainfall Forecasting Results Comparing Number of Layers Hidden (LP) in Networking Training Processes

\begin{tabular}{|c|c|c|c|c|c|}
\hline \multirow{3}{*}{ Period } & \multirow{3}{*}{ Rainfall/CH (mm) } & \multicolumn{4}{|c|}{ Neural Network (Architecture) } \\
\hline & & \multicolumn{2}{|c|}{$\begin{array}{l}1 \mathrm{LP} \\
5,1,1\end{array}$} & \multicolumn{2}{|c|}{$\begin{array}{l}2 \mathrm{LP} \\
5,1,1,1\end{array}$} \\
\hline & & $\mathbf{C H}$ & Error (\%) & $\mathbf{C H}$ & Error $(\%)$ \\
\hline Jan-08 & 258,9 & 369,7 & 43 & 370,1 & 43 \\
\hline Feb-08 & 241,8 & 157,3 & 35 & 157,5 & 35 \\
\hline Mar-08 & 326,9 & 391,5 & 20 & 391,8 & 20 \\
\hline \multicolumn{6}{|l|}{$\vdots$} \\
\hline Okt-16 & 260,0 & 282,9 & 9 & 282,2 & 9 \\
\hline Nov-16 & 368,0 & 281,3 & 24 & 280,8 & 24 \\
\hline Des-16 & 267,1 & 263,9 & 1 & 263,5 & 1 \\
\hline Mean & 329,8 & 329,8 & 55 & 329,8 & 55 \\
\hline Correlation Coefisien & - & & & & 0,67 \\
\hline
\end{tabular}

The results of training is displayed on table 1. From the result of forecasting in the network training process, we can obtained that average of error for each hidden layer has the same value. As for the correlation between the actual data with the result of forecasting for 1 hidden screen and 2 hidden screens have no significant difference. Therefore, taking into consideration the efficiency of the forecasting process, one hidden layer is selected for the backpropagation neural network model . 


\subsection{Training for the number of neurons in the hidden layer}

The results of rainfall forecasting compare the number of neurons in the hidden layer in the network training process is displayed on table 2 and table 3 .

Table 2. Rainfall Forecasting Results Comparing Number of Neurons in the Hidden Layer of Network Training Process

\begin{tabular}{|c|c|c|c|c|c|c|c|}
\hline \multirow{3}{*}{ Period } & \multirow{3}{*}{ Rainfall/CH (mm) } & \multicolumn{6}{|c|}{ Architecture } \\
\hline & & \multicolumn{2}{|c|}{$5,1,1$} & \multicolumn{2}{|c|}{$5,2,1$} & \multicolumn{2}{|c|}{$5,3,1$} \\
\hline & & $\mathbf{C H}$ & $\begin{array}{l}\text { Error } \\
(\%)\end{array}$ & CH & $\begin{array}{c}\text { Error } \\
(\%)\end{array}$ & CH & $\begin{array}{l}\text { Error } \\
(\%)\end{array}$ \\
\hline Jan-08 & 258,9 & 369,7 & 43 & 458,3 & 77 & 317,2 & 23 \\
\hline Feb-08 & 241,8 & 157,3 & 35 & 158,9 & 34 & 213,9 & 12 \\
\hline Mar-08 & 326,9 & 391,5 & 20 & 453,6 & 39 & 510,1 & 56 \\
\hline \multicolumn{8}{|l|}{$\vdots$} \\
\hline Okt-16 & 260,0 & 282,9 & 9 & 289,2 & 11 & 282,7 & 9 \\
\hline Nov-16 & 368,0 & 281,3 & 24 & 328,2 & 11 & 439,1 & 19 \\
\hline Des-16 & 267,1 & 263,9 & 1 & 270,4 & 1 & 308,9 & 16 \\
\hline Mean & 329,8 & 329,8 & 55 & 329,8 & 50 & 329,8 & 42 \\
\hline Correlation Coefisien & - & \multicolumn{2}{|c|}{0,67} & \multicolumn{2}{|c|}{0,73} & \multicolumn{2}{|c|}{0,81} \\
\hline
\end{tabular}

Table 3. Rainfall Forecast Results Comparing Number of Neurons in Hidden Layers on Networking Training Processes

\begin{tabular}{lccccc}
\hline & & \multicolumn{3}{c}{ Architecture } \\
Period & Rainfall/CH (mm) & \multicolumn{5}{c}{$\mathbf{4 , 1}$} & \multicolumn{2}{c}{$\mathbf{5 , 5 , 1}$} \\
& & CH & Error (\%) & CH & Error (\%) \\
\hline Jan-08 & 258,9 & 478,6 & 85 & 312,2 & 21 \\
Feb-08 & 241,8 & 180,5 & 25 & 295,9 & 22 \\
Mar-08 & 326,9 & 372,9 & 14 & 525,7 & 61 \\
$\vdots$ & & & & & \\
Okt-16 & 260,0 & 249,3 & 4 & 188,3 & 28 \\
Nov-16 & 368,0 & 367,2 & 0 & 440,1 & 20 \\
Des-16 & 267,1 & 254,5 & 5 & 228,3 & 15 \\
\hline \multicolumn{1}{c}{ Mean } & 329,8 & 329,8 & 43 & 329,8 & 25 \\
\hline Correlation Coefisien & - & 0,79 & & 0,89 & \\
\hline
\end{tabular}




\subsection{Testing the backpropagation neural network model}

Results testing network is displayed on table 4. From the three models tested network architecture, it was found that the architecture model $(5,4,1)$ has a value of correlation and RMSE values better compared with 2 other network architecture models.

Table 4. Rainfall Forecast Results Comparing Number of Neurons in Hidden Layers on Networking Training Processes

\begin{tabular}{lcccc}
\hline & & \multicolumn{3}{c}{ Architeture } \\
Period & Rainfall/CH (mm) & $\mathbf{5 , 3 , 1}$ & $\mathbf{5 , 4 , 1}$ & $\mathbf{5 , 5 , 1}$ \\
& & $\mathbf{C H}(\mathbf{m m})$ & $\mathbf{C H}(\mathbf{m m})$ & $\mathbf{C H}(\mathbf{m m})$ \\
\hline Jan-17 & 325,8 & 274,6 & 203,1 & 306,2 \\
Feb-17 & 235,3 & 224,5 & 180,6 & 295,2 \\
Mar-17 & 491,4 & 308,0 & 422,5 & 315,8 \\
Apr-17 & 418,0 & 423,9 & 345,5 & 360,0 \\
Mei-17 & 414,0 & 493,5 & 454,4 \\
Jun-17 & 658,4 & 424,4 & 440,4 & 455,1 \\
Jul-17 & 407,1 & 283,8 & 338,7 & 306,6 \\
\hline Correlation Coefisien & 253,0 & 0,69 & 0,81 & 0,70 \\
\hline RMSE & & 117,94 & 95,41 & 110,18 \\
\hline
\end{tabular}

4.4 Forecasting

We can see the results forecasting of rainfall in North Luwu period August 2017 to December 2017 using backpropagation neural network method with architecture $(5,4,1)$ in table 5 .

Table 4. Rainfall Forecast Results Comparing Number of Neurons in Hidden Layers on Networking Training Processes

\begin{tabular}{cc}
\hline Period & Rainfall $(\mathbf{m m})$ \\
\hline Aug-17 & 164,2 \\
Sep-17 & 247,7 \\
Oct-17 & 76,3 \\
Nov-17 & 76,3 \\
Des-17 & 158,8 \\
\hline
\end{tabular}

\section{Conclusion}

Rainfall forecasting in Luwu Utara using the method backpropagation neural network obtained architectural model $(5,4,1)$ that correlation value and RMSE between the 
actual data with the result of the forecasting show that the backpropagation neural network method provides the results are quite accurate with value of RMSE : 95,41.

\section{References}

[1] Ahmar, A.S., Guritno, S., Abdurakhman, Rahman, A., Awi, Alimuddin, Minggi, I., Tiro, M.A., Aidid, M.K., Annas, S., Sutiksno, D.U., Ahmar, D.S., Ahmar, K.H., Ahmar, A.A., Zaki, A., Arifin, A.N.M.: Modeling Data Containing Outliers using ARIMA Additive Outlier (ARIMA-AO). J. Phys. Conf. Ser. 954, 01010 (2018).

[2] Ahmar, A.S., GS, A.D., Listyorini, T., Sugianto, C.A., Yuniningsih, Y., Rahim, R., Kurniasih, N.: Implementation of the ARIMA(p,d,q) method to forecasting CPI Data using forecast package in R Software. J. Phys. Conf. Ser. 1028, 012189 (2018).

[3] Sutiksno, D.U., Ahmar, A.S., Kurniasih, N., Susanto, E., Leiwakabessy, A.: Forecasting Historical Data of Bitcoin using ARIMA and $\alpha$-Sutte Indicator. J. Phys. Conf. Ser. 1028, 012194 (2018).

[4] Kurniasih, N., Ahmar, A.S., Hidayat, D.R., Agustin, H., Rizal, E.: Forecasting Infant Mortality Rate for China: A Comparison Between $\alpha$-Sutte Indicator, ARIMA, and Holt-Winters. J. Phys. Conf. Ser. 1028, 012195 (2018).

[5] Khuat, T.T., Le, M.H.: An Application of Artificial Neural Networks and Fuzzy Logic on the Stock Price Prediction Problem. JOIV Int. J. Informatics Vis. 1, 40-49 (2017).

[6] Shodiq, M.N., Kusuma, D.H., Rifqi, M.G., Barakbah, A.R., Harsono, T.: Neural Network for Earthquake Prediction Based on Automatic Clustering in Indonesia. JOIV Int. J. Informatics Vis. 2, 37-43 (2018).

[7] Alsamhi, S. H., Ansari, M., Hebah, M., Ahmed, A., Hatem, A., \& Alasali, M.: Adaptive Handoff Prediction and Appreciate Decision Using ANFIS between Terrestrial Communication and HAP.

[8] Pranolo, A., ammurrohman, F.I., Hendriana, Y., Octaviani, D.: A Decision Support System using ANFIS to Determine the Major of Prospective Students in A Vocational School of Indonesia. Int. J. Comput. Trends Technol. 27, 100-105 (2015).

[9] Fausett, L. V: Fundamentals of neural networks: architectures, algorithms, and applications. Prentice-hall Englewood Cliffs (1994).

[10] Özel, T., Nadgir, A.: Prediction of flank wear by using back propagation neural network modeling when cutting hardened H-13 steel with chamfered and honed CBN tools. Int. J. Mach. Tools Manuf. (2002). 